\title{
Introduction: Italian Intellectuals and International Politics
}

Andrea Guiso $1 \otimes$

Alessandra Tarquini $1 \otimes$

Sapienza University of Rome, Rome, Italy

\section{Abstract}

The abstract is published online only. If you did not include a short abstract for the online version when you submitted the manuscript, the first paragraph or the first 10 lines of the chapter will be displayed here. If possible, please provide us with an informative abstract.

The period between the end of the Second World War and the signing of the Maastricht Treaty was full of change for the placing of Italy in the international scenario. It was marked by the inclusion of the country in the open and multilateral context of the alliance between Europe and the United States. The chapter aims to understand how Italian intellectuals interpreted, discussed and influenced international politics in this historical period. Bringing together contributions from historians coming from different cultural and methodological backgrounds, the authors try to answer the following questions: how did intellectuals contribute to the elaboration of the Republic's international politics? Did the bipolar logic, imposed by the Cold War, and the idea of belonging or being close to a party have a significant influence on the intellectuals' way of thinking or was, for the examined period of time, their vision autonomous from politics? Has this autonomy had an effect on the public debate? Although the answers to these questions will no doubt be different for each of the case studies - as the figures and problems discussed in the various essays represent very different experiences - we still think it is possible to point out some common qualities.

\subsection{Research Subject and Methodologies}

This book brings together contributions from historians coming from different cultural and methodological backgrounds, gathered around a common idea: understanding how Italian intellectuals interpreted, discussed and influenced international politics between the end of the Second World War and the signing of the Maastricht Treaty, the most politically demanding act of a united Europe after the collapse of the Soviet system. The period between the end of the Second World War and the signing of the Maastricht Treaty is a historical period full of change, marked by the inclusion of Italy in the open and multilateral context of the alliance between Europe and the United States, the alliance destined to become a structural component of Italian democracy and its political and institutional dynamics for almost 50 years. ${ }^{1}$ This volume answers the following questions: in the years dealt with, years during which the world was going through a major transformation, what was the contribution of Italian intellectuals to the main issues of international politics? Did the bipolar logic imposed by the Cold War, and the idea of belonging or being close to a party, have a significant influence on the intellectuals' way of thinking or was, for the examined period of time, their vision autonomous from politics? 
The presence of loyalty ties with political parties has deeply affected the life of the country, generating a permanent conflict of ideas, feelings and passions about the role of Italy in the global scenario, but also and above all about the major issues of international politics, after the severe trauma of a military defeat, the bloody epilogue of the civil war and the start of a constituent phase on which the shadow of the Cold War would soon be cast. ${ }^{2}$ Intellectuals were important protagonists in that conflict in the history of the so-called First Republic and had roles that reflected their different positions in the national alignments and their different levels of involvement in the forms of civil commitment and political militancy of the time.

The most innovative element of this volume is the attempt to highlight, through some case studies, a theme - that of the relationship between intellectuals and foreign policy-long ignored by international studies as an autonomous subject for reflection. ${ }^{3}$ This situation has likewise not been helped by the renewed interest of specialists - especially Cold War scholars - for the cultural aspects of diplomacy or international policy making. ${ }^{4}$ Even in this limited field of study, the role of intellectuals has mostly been treated as a side effect of the broader context of the Total Cold War and of the birth of transnational intellectual networks operating in a more or less direct link with national government institutions. Although a considerable amount of work has been produced on the leading figures of the world of culture and international political debate, on the whole this effort has been directed more toward the individuals or certain political cultures than toward intellectuals as a social group. The visions of the world that they produced, the roles they had, their ability to influence public opinion and their ability to shape collective speech, in agreement or in disagreement with politics and with those in power, ${ }^{7}$ have been underestimated.

The authors of the chapters collected here, aware of the fact that problems of this magnitude cannot be solved in the context of a single piece of research, however wide-ranging and extensive, are still convinced that the investigation that the reader will have the patience to follow through the chapters of this book is beneficial. This conviction is based on a methodological and historiographical consideration, which concerns the importance of the Italian case for a more general reflection on the political role of intellectuals.

\subsection{The Importance of the Italian Case}

Italy is a clear example of the crucial function that intellectuals, and in particular intellectuals working in the field of humanities, have held in public discourse since the beginning of the twentieth century. Since then, the purpose of the ruling class to build a modern nation, the socalled "nationalization of the masses" (one of George Mosse's concepts that has now entered the vocabulary of social scientists), had been based on the celebration of myths, rituals and symbols capable of manifesting the reasons for a new relationship and had become an expression of a nationalism that combined the idea of country with the principle of freedom. This idea takes its origins during the Enlightenment and the French Revolution and represents pride in belonging to a great nation, the certainty that legitimacy of the self-determination of peoples is based on popular sovereignty. And indeed, in Italy as well, among intellectuals engaged in the reflection on national identity, an idea of nation had prevailed, as a consequence of the intellectual and moral emancipation of citizens fighting for freedom.

In the early years of the twentieth century, this project was criticized by new political subjects, artistic avant-gardes and numerous intellectuals who joined the traditional opponents of the liberal elite because they considered it an illegitimate and corrupt power system. ${ }^{9}$ Politicians and intellectuals believed that the Italian ruling class was not capable of managing the new issues posed by industrialization and mass society and were convinced that it was necessary to give life 
to a radical transformation of the country in order to develop its national consciousness and a new role in the world. For this reason, they presented themselves to public opinion as the true representatives of the nation, the only guardians of the national myth, and from then on participated with enthusiasm in a discussion concerning foreign policy, the present and the future of the country. A sense of angry indignation spread among them along with harsh criticism of a policy judged incapable of keeping faith with the hopes and ideals of Risorgimento patriotism, increasingly withdrawn into a patronizing management of power, devoid of the impulses and ambitions of a strong and respected country.

From this point of view, the 1911 Italo-Turkish War spread "a flare of enthusiasm and nationalist rhetoric that was added to the rhetoric of the fiftieth anniversary [of the Italian Republic], but what proved to be even more effective was popularization of the myth of a Great Italy through journalism, literature, academic culture, and theatrical performances". 10 In those months, artists, scholars, men and women of culture, from literature to philosophy, from cinema to historiography, were willing to show their presence by introducing themes that would define the debate of the decade from 1912 to 1922; and for the first time they presented themselves to Italian society "in the dual function of suppliers of ideas and propagandists of the same" taking on a new role. "They were not alone: far from the tones and literary representations of the country, even jurists, social scientists and politicians, economists - intellectuals in the broadest sense of the term-were cultivating the idea of a profound osmosis between culture and politics.

It is clear, however, that the substantial change in the relations between the two spheres occurred during fascism. By subordinating culture to politics, the Mussolini regime also helped define a specific function of intellectuals in the era of the primacy of politics. From 1922 to 1945, men of culture and science took on an organic role in politics, both as officials and professionals of propaganda and indoctrination in organizational structures and in the media system of the totalitarian state, and as theorists and planners of the new political regime and its lines of institutional, administrative, economic and social development. The fascists celebrated the primacy of politics over all the other manifestations of modern life and considered culture an instrument for creating the new civilization which was born with the seizure of power in October 1922. We can observe that in the first lines of the volume La cultura fascista (The fascist culture), published in 1936 by the National Fascist Party for courses of political preparation for young people. What we read in that volume is that "a culture is a conception of life", "a manifestation of social, spiritual and historical action" and not an "individual way of being", "an embellishment of the intellect or a private contemplation". Culture, in essence, is an activity that "forms a people". 12 The majority of intellectuals, artists and technicians worked in accordance with these assumptions and contributed to the construction of the totalitarian regime that guaranteed them an unprecedented space and role.

Republican Italy inherited this tradition by revamping some aspects and adapting them to a deeply transformed context. In fact, the leading mass parties - the Christian democrats, the Communist Party and the Socialist Party, but also the smaller formations - even though their political and cultural identities were quite different, all demonstrated significant attention to intellectuals from the early years of reconstruction. And in turn intellectuals contributed to the symbolic construction of the new world that emerged after the war. Clearly, in a republican and democratic country, men of culture do not have the same kind of relationship with politics and with institutions as in a totalitarian regime, in which political dissent is persecuted and the actual confrontation between the opposing politics and visions are not possible. By forbidding pluralism and building a singleparty dictatorship, Mussolini's regime allowed the confrontation between intellectuals only within the institutions and mostly on such topics as politics, myths and the ideology of fascism. 
Nevertheless, during the years of the Cold War, an era of definitive and absolute choices, intellectuals lived literally immersed in politics, in an all-encompassing relationship with the parties, and with the deployment to which they claimed to belong, showing they still believed in the centrality of the relationship between politics and culture. Many of them signed up to the parties, some of them actually became party officials, others held important roles in national and international institutions and organizations, and others still discussed as 'independents' with both the government and the opposition forces, called on to express the political culture or cultures that would become the basis of the new idea of a nation and its projection into the world.

\subsection{Intellectuals and the Political Cultures of Republican Italy in the Context of the Cold War}

In the aftermath of fascism, the democratic parties, which did not declare themselves nationalist and on the contrary considered nationalism the main matrix of the totalitarian regimes of the 1920s and 1930s, ended up appropriating the evocative power of the nation since they were aware of its utility as a powerful identity resource. ${ }^{14}$ The participation of the parties in the Resistance had been an opportunity to restore, with many elements of ambiguity and instrumentality, images and symbols of the battle for national unification, for which the left parties presented themselves as the true heirs of the Risorgimento tradition and capable of freeing the country from the fascist enemy and its National Socialist ally. Democrazia Cristiana (DC-Christian Democracy) presented itself to militants, voters and the entire public opinion as a national party, able to address all Italians in the name of an inter-class catholic culture that embraced wide and diverse sectors of society.

In fact, Italian intellectuals who saw the world through the lens of the Cold War did not fully share that common feeling that builds the cultural and civil fabric of a nation. From this point of view, the nationalization of the masses operated by liberal Italy and constrained by the structures of the totalitarian state came across more than one obstacle in republican history since what divided the most authoritative exponents of Italian culture was certainly stronger and more significant than what united them. The primacy of politics, inherited from fascism, prevailed over the strength of national institutions, which remained hostage to party divisions. ${ }^{15}$

As we will see on the following pages, the protagonists of this book were representatives of the three great post-war political cultures - catholic, marxist and liberal-democratic. Bearers of incompatible and antagonistic visions of the world, the representatives of the three cultures had very different approaches to the most important topics regarding international politics. Certainly, during the period considered in the volume, the meaning of being left or being liberal has changed significantly. And after all there is no univocal correspondence between an ideology and the subjects that express it: ideology is a complex of visions, myths and values, capable of directing political action and expressing a conception of the world, and not a coherent and systematic philosophy that provides for a certain behavior. ${ }^{16}$ Every political movement always presents a degree of discordance or inconsistency between the goals set and the concrete way of operating in a given reality.

Nevertheless, it is possible to identify some common characteristics within each political and cultural group and for that reason this volume is divided into three distinct parts. We begin with the catholic culture, which was of great importance due to the role played by the DC as a ruling party from 1945 until 1992. The DC was responsible for Italy's accession to the North Atlantic Treaty Organization (NATO) and the European Community in general and was the main supporter of the pro-Western direction in politics. The formation of a catholic-inspired ruling class was the result of a process of complex cultural stratification, the roots of which, however, were not 
connected exclusively to the broad presence of the Church in Italian history. The identity of the DC, in fact, takes its origins in the experience of the Partito popolare italiano (PPI-Italian Popular Party) after the First World War, as well as in Luigi Sturzo's attempt to include catholics in the secular state through the actions and program of a party of a "non-denominational" nature. The lukewarm involvement of the Holy See in Sturzo's project and the advent of fascism in power had sanctioned the temporary defeat of this perspective, destined to re-emerge forcefully at the end of the Second World War under the guidance of Alcide De Gasperi. It was, however, within the framework of the fascist regime that the meeting between catholics and the State, supported by the centralizing action and reorganization of the catholic movement initiated in those years by Pius XI, was able to mature further, albeit in ambivalent and contradictory terms, given the coexistence in the catholic world of more conservative and more daring ideological-cultural contaminations. In this climate, thanks also to the mediation of Msgr. Montini, who later became Pope taking the name of Paul VI, a new generation of future catholic leaders was formed from the late 1930s. Those leaders were coming from the lower- and upper-middle-class intellectual bourgeoisie and were deeply linked to the ecclesiastical institution as an identity body rooted in time and history, and at the same time culturally sensitive to the transformations of the modern world, to the growing importance of macroeconomic factors and to the role of the party and of public power in the governance of a modern mass society. ${ }^{18}$ They represented a second generation, destined to have little political weight in the aftermath of the war, but enormous influence in the cultural debate and in the elaboration of the ideal and "programmatic" qualities of the new republican constitution. 19

The problem of the international positioning of the country in the aftermath of the conflict and in the context of the rapid deterioration of relations between the powers of the anti-Nazi coalition emphasized this diversity and heterogeneity of ideas within the catholic world. The birth of a single-colored Christian democratic government in May 1947 and the simultaneous repositioning of Italian foreign policy and the Holy See in the framework of closer political and economic ties with the United States marked the first serious moment of tension in relations between different components of the Christian democratic world. And in particular between De Gasperi's centrist leadership and the catholic-democratic power animated by Giuseppe Dossetti and the magazine Cronache sociali, a power that was fundamentally opposed to the breakdown of dialogue with marxist-inspired parties and a foreign policy of the country considered too crushed by the US strategy of containment. ${ }^{20}$ Nevertheless, the Cold War would turn out to be the true bonding force of the political unity of catholics, a fundamental presupposition and condition of the Christian democratic party in the Italian political system and of the reintegration of the country in an open, multilateral and cooperative international relations context. That unity was meant, and not by chance, to fade away precisely in the moment when the tension in the political and ideological conflict between the West and the communist world was declining. ${ }^{21}$

The chapters by Andrea Guiso, Giovanni Mario Ceci and Massimo De Giuseppe go through these different phases, showing the variety of themes, the protagonists, the interests, the specifics of a catholic world that embraces culturally heterogeneous international options: from Atlanticism to pacifism, from the vatican Ostpolitik to third worldism up to the "neo-Atlanticist" suggestions of Italy as a "bridge" between Europe and Africa or the Middle East. As we learn from Ceci's: chapter, there were those who rethought modernity in a critical and radical way, like the philosopher Del Noce, who linked his own reflection against Western modernity to the evolution of détente. Convinced that the modern world had brought about an eclipse of traditional values that would lead to absolute immanentism and relativism, he saw the signs of that eclipse in the birth of the new international equilibrium. Del Noce anticipated a way of reading international politics that would become very popular in the coming years. In his chapter Massimo De 
Giuseppe contradicts the idea of a catholic culture always ready to support American power and the Western world and highlights the role of catholics as protagonists of a profound cultural renewal of the relations between the South and North of the world, accrued on the basis of the theological innovations promoted by the Second Vatican Council. The case of Beniamino Andreatta, an exponent of the Christian democratic left, described in Guiso's chapter, tells the story of a strong and non-negotiable cultural and political link between Atlanticism and Europeanism. But at the same time, that case demonstrates the evolution of a relationship between Italy and Europe, destined to take on the form of a vincolo esterno (external constraint) for the State reform based on the "orthopedic" use of European legislation to induce the political class to face up to the problems of administrative efficiency, the public morality of the parties and the governability of the Italian State. The passage from this position to the claim of a role of supplenza politica (political substitution) by technostructures and competent intellectuals operating up the chain connecting national government and European institutions would be very short. The figure of the secular and liberal banker Guido Carli, described by Caviglia in his chapter, also appears emblematic in that sense, since it is symptomatic of the presence of a transversal government culture that inferred political change as a consequence of a managerial revolution from above. It would be destined to become a hegemon in the framework of a long process of loss of proactive coherence and legitimacy of national politics against the background of the crisis of monetary stability, the processes of financial globalization and the consequent fall of sovereignty of the national state.

The conversation was quite different for the numerous exponents of the great socialist family of marxist matrix - socialists, social democrats, communists. This group had enormous consensus and in 1975 represented half of the electoral body in Italy. From this point of view, Italy has a different history from that of other European countries: unlike what happened in the rest of Europe, from 1945 the Italian left was represented by the Partito socialista italiano (PSI-Italian Socialist Party) and the Partito comunista italiano (PCI - Italian Communist Party), allies in a position of clear supremacy compared to the social democrats, who for the next four decades would remain a small party, ready to support the governments led by the Christian democrats. It was a choice that had impressive consequences "in the historical definition of the relationship between politics, ideology and culture of Italian socialism". 22 The PSI was in dialogue with the left wing of European socialist parties and not with Labor, was not a member of the Socialist International, was reborn as an organization of social-democratic parties in 1951, and took up a neutralist position in the international arena. ${ }^{23}$ According to many historians, this neutralism resulted in an ambiguous policy, given the alliance with the Communist Party which, after the creation of Cominform, started acting more and more clearly in strict adherence to Soviet directives. ${ }^{24}$ In fact, this neutralist choice turned into pro-Soviet pacifism because the socialists believed that "the equidistance from both Moscow, capital of the socialist revolution, and Washington, capital of imperialism" 25 was not possible. The PSI, linked to the PCI, was under the influence of the Soviet Union and until the late 1960s the PSI expressed a political culture that, although not Stalinist, was decidedly pro-Soviet, derived from Marxism-Leninism, and struggled to propose an independent reflection.

The PCI was not split up into currents comparable to that of the socialists. Its secretary, Palmiro Togliatti, had been working hard to re-establish the party, transforming the small revolutionary formation of the 1920s into a mass party, which had its reference point in marxism-leninism, and was engaged in spreading a new culture. For this reason, after the war, the PCI was full of initiatives and publications addressed to militants but also to a wider public. ${ }^{26}$ After an initial and tactical adhesion to a multilateral approach to international problems, which envisaged the alliance between the victorious powers of the Second World War, the PCI became a supporter of a foreign 
policy faithful to that of the Soviets, which in fact was brought into question only at the end of the 1960s.

This is demonstrated in the chapter by Paola Lo Cascio who describes a party linked to bipolar logic, a party that supported the interpretation of the past, anchored in the anti-fascist struggle, an important element of the communists' identity. The young Rossana Rossanda, who in 1969 was one of the founders of the dissident communist group of Manifesto and for this reason was removed by the PCI, was sent by Togliatti to Spain in 1962 to make contact with a number of intellectuals and give life to a unified solidarity initiative against Francoism. It is an emblematic story: for the left of the whole world, Spain had been the first major testing ground of the antifascist struggle that had not only lost the civil war but also had not succeeded in wiping out Francoism even after the Second World War. On the contrary, the new balances of the Cold War had guaranteed its consolidation, by raising a series of questions about the dictatorships of the 1930 s, their characteristics and their modernity. Not always were communist intellectuals up to the challenge presented to them by the great events of international politics. Gregorio Sorgonal reconstructs the impact of Ronald Reagan's presidency on communist culture focusing in particular on politics, society and the US economy of three prominent intellectuals in the communist culture of the 1980s. As we can see from his analysis, the image of Reagan's America offered by these scholars clearly shows how the communist culture portrays American modernity, why it does not capture the birth of the new right, which aspects of that phenomenon are being considered and which ones are completely ignored, as well as the evolution of the relationship with marxism, the ideological basis of the PCI. In fact, the reflection on the ideological assumptions was decidedly neglected in many reflections of Italian communists, as also shown by Enrico Serventi Longhi in his chapter on the Confederazione Generale Italiana del Lavoro (CGIL-Italian General Confederation of Labor), the main Italian trade union of socialist and communist matrix. The world of work proved to be particularly attentive to the events that since the end of the 1970s had led Solidarnosc to acquire strength and capacity for the intervention in communist Poland. According to the Italian trade unionists of the CGIL, the Polish example showed how the national, religious and democratic conscience could overcome classconsciousness in the traditional sense. However, the events linked to the collapse of popular democracies did not produce a new sense of belonging in the workers' base and sharpened a profound disorientation that contributed to the crisis of identity and legitimacy of the trade union in the second half of the 1980s.

The history of the PSI differed from that of the communists only starting in the beginning of the 1970s, as shown in the chapters by Alessandra Tarquini and Gianluca Scroccu. Alessandra Tarquini has reconstructed the way in which the main exponents of the Italian left confronted the problem of anti-Semitism and the Arab-Israeli question from 1948 to 1956. Socialists and communists, unwilling to present themselves to the public and the world as the protagonists of the rebirth of democracy, did not address either the persecution of the Jews of the 1930s and 1940s or the anti-Semitic demonstrations in the USSR of the 1950s. The difficulty they had in analyzing anti-Semitism was expressed in the same years in which left-wing intellectuals and politicians spoke about the Arab-Israeli conflict. And if in 1948 they had been the main supporters of Israel, in 1956, during the Suez war, they supported Colonel Nasser in criticizing the politics of Israel, which then was considered a country friendly to the United States, and therefore enslaved to imperialism. At the end of the next decade, the path of the Italian left split into two different reflections, two reflections that alienated both socialists and communists, as also underlined by Scroccu in his work on postcolonial Africa in the political culture of Italian socialism.

In his chapter, Scroccu identifies two different periods: the first one, from 1955 to 1973, during 
which prevails a strict anti-Western and anti-imperialist marxist approach to the geopolitical and social transformations of Africa; the second one, developed after the mid-1970s, was the result of the reflection around inequalities between the North and the South of the world. From then on, a reflection on postcolonialism similar to that of the political culture of European social democracy has become common among Italian socialists. That reflection consisted in the intuition that the North-South axis had definitively supplanted the East-West one and that the battles for affirmation of the principles of socialism, and human rights, was definitely supposed to move in that direction.

It was, in fact, an approach to the liberal-democratic culture that in Italy had found many obstacles. Crushed by the large mass parties, stuck between the great historiographic interpretations proposed by the communists and the socialists, the intellectuals of the Italian liberal-democratic left did not join a single political group or movement: divided between the Socialist Party, the Radical Party, the Republican Party and the Social Democratic Party, between 1945 and the Maastricht Treaty, they were among the most attentive observers of international politics, as shown by the chapters by Marco Bresciani, Laura Ciglioni and Donatello Aramini, and Luca Polese Remaggi.

In his chapter, Marco Bresciani has reconstructed the reaction of several well-known intellectuals and politicians who had taken part in the anti-fascist Giustizia e Libertà (Justice and Freedom) movement on the Hungarian uprising of 1956. He shows how the debate around the transformations of the post-Stalinist Soviet world as well as the expectations of the Hungarian revolution allowed for a renewal of the reflection on the relationship between socialism and communism, and more generally on the relationship between democracy and totalitarian regimes: a theme that in the early 1950s constituted a factor of division between the democratic left and communists. During 1956, the protagonists of Bresciani's work pointed out the uncertainties, silences, removals and omissions of the marxists and demonstrated the central and never-resolved nature of the relationship between ethics and politics. In reality, this non-communist left represented a decidedly varied and complex world. A few years before the Soviet invasion of Hungary in 1951, a group of young graduates from the University of Bologna gave life to the magazine Il Mulino. Liberals but not in favor of laissez-faire, catholics but not fundamentalists, socialists but not communists, in short reformists and democrats, the collaborators of the magazine were certainly driven more by the social sciences than by the traditional humanistic culture. According to them, the intellectual played a key role, a role of a technical advisor whose function was to contribute to the continuous extension of the boundaries of the welfare society, and of a transmission belt between elites and society. This figure was meant to be open to new social sciences and to produce the orientations and ideas that would direct the politics. Pragmatism was at the center of their cultural analysis, even in matters of foreign policy. That is why the Mulino intellectuals proposed a vision that united the ideal of democracy and a realist approach to international politics, an approach based on the traditional logic of power. In this sense, the Bolognese magazine - as Aramini and Ciglionil point out in their essay - can be considered an expression of that season of reformism, and of trust in the social sciences as instruments of intervention and transformation of society, reached its peak in the 1960s. ${ }^{28}$ The United States, with its power of attraction and influence, undoubtedly had a fundamental role in that process. In a long-term perspective though - as Mario Del Pero has shown about Roosevelt's New Deal, whose lesson and reworking was a crucial moment of that cultural season - that process was also "the result of exchange, interaction and transnational, or at least transatlantic, hybridization", in which the United States were "often receiving subjects". 29

The reflection on the balance of the Cold War was not without ambiguity, as Luca Polese Remaggi points out in his chapter on communist China and on the journeys that politicians and scholars of 
the Action Party's (Partito d'Azione) area made in the 1950s. In their attempt to regenerate the idea of political and social revolution, men of proven democratic faith who had condemned totalitarian regimes, witnesses to the fascist violence of which they had been fierce opponents, saw in Mao's China the possibility of experimenting with a new way of doing politics. For this reason, distinguished jurists, men of government, philosophers and scholars, mostly heirs of the liberal and democratic socialist tradition, considered the large-scale violence that the Chinese communist regime perpetrated in order to build a new type of society, necessary and legitimate. Clearly, as Polese points out, Italians were not the only ones: in the context of the Cold War, throughout Europe, non-communist left-wing intellectuals showed a certain propensity to grant revolutionary power the right to suspend the establishment of civil liberties and policies, that is, the whole system of guarantees of the rule of law, in view of the enormous task of promoting the liberation of huge human masses from poverty and exploitation. Clearly, such inclination was unthinkable in Western Europe and, ultimately, even the events that took place beyond the iron curtain, in the European countries included in the Soviet bloc, were looked upon with disregard. In the mindset of intellectuals from the universe of former Action Party, however, revolutionary experimentalism, with its load of old socialist and nationalist mythologies, was taking place in the distant countries, such as China, and they did not think much about what was actually happening in Beijing after the establishment of the popular Republic in October 1949. This story raises more than one question about the relationship between democracy and totalitarian regimes, on the meaning of Western democracy, on the kind of evolution that the end of the Cold War would bring about.

The absence from these pages of exponents or figures belonging to the field of the right does not imply any value judgment. The choice of the curators was that of giving priority to the relationship between the intellectuals and cultures that have most influenced the international positioning of the country and its foreign policy. ${ }^{30}$ The pro-Atlantic choice, with its essential anti-communist connotation, had certainly been for the neo-fascist Movimento sociale italiano (MSI-Italian Social Movement) an act of considerable symbolic and political value, aimed at removing the antifascist legitimization. Neo-fascists in fact hope that their adamant pro-Atlantic commitment would serve to get close the government majority area. And yet, the prospect of full constitutionalization of the MSI sealed by the choice of a pro-Western field has caused concern in the ruling and opposition parties, unwilling, for various reasons, to call into question the discriminating ethics of anti-fascism, but also encountered strong resistance within the neo-fascist party. The resistance inside MSI was posed by both the leftist "social-national" components of "immense and red" fascism, culturally hostile to the rationalist and mechanistic civilization from across the ocean, and from the spiritualist and anti-modern groups that embraced the ideas of the traditionalist philosopher (with anti-Semitic hues) Julius Evola. ${ }^{31}$ Both of these components were very influential among the young neo-fascists and firm, despite their substantial public irrelevance, in their rejection of the logic of blockades.

However, the international political system of the Cold War did not represent a static universe. Since the mid-1950s, the relationship between the center and the periphery of the global conflict had tended to be decidedly more complicated. In fact, the relative decline of the Cold War in Europe corresponded to a more intense and prolonged phase of tensions in geographic areas which previously were mostly unaffected by the bipolar conflict. Influential powers and actors at the local and regional levels, who would see a growing possibility to gain weight in the global political balance and in the dynamics of relations between the two superpowers, would end up taking advantage of the situation. At the end of the 1960s, these events ended up intertwined with the double crisis of the Soviet model and of American hegemony and got engaged in the contextual revolution of moral languages, forms of communication and diffusion of thought, of the representativeness of international government. Once again the international political system, in its 
incessant evolution, would change Italy and its way of representing itself in the context of the global Cold War and would pull it into the center of a dynamic yet unstable dimension of international relations, marked by new critical fault lines of various entity and nature: ethical, social, religious, cultural, political, economic and scientific-technological. The political cultures and ideas of the intellectuals would end up changing, together with the national and global scenarios that they themselves tried to interpret and explain, moving away - without ever completely denying them-from preconceived visions and international ties of political and ideological order that had characterized the "battle of ideas" in the early years of the country's reconstruction.

\subsection{The Role of Italian Intellectuals in International Politics: Possible Interpretations}

In conclusion to this introduction, we would like to emphasize several possible interpretations of the relationship between Italian intellectuals and international politics. When working on our research, we asked ourselves several questions: how did intellectuals contribute to the elaboration of the Republic's international politics? Did the bipolar logic, imposed by the Cold War, and the idea of belonging or being close to a party, have a significant influence on the intellectuals' way of thinking or was their vision autonomous from politics? Has this autonomy had an effect on the public debate? Although the answers to these questions will no doubt be different for each of the case studies - as the figures and problems discussed in the various essays represent very different experiences - we still think it is possible to point out some common qualities.

One theme that reappears throughout the various essays is the ardent engagement of Italian intellectuals in the most important topics of international politics. From 1945 to 1992, Italian intellectuals felt it was their duty to contribute to and guide the public debate on important topics introduced by the Cold War, questions raised by de-colonization, as well as the problem of European integration and the relationship between the Old Continent and the United States. These intellectuals, bearers of a tradition rooted in the Italian Unification experience, sought to contribute to the world's transformation, not limiting their contribution to internal political matters. Even those intellectuals who were not directly or professionally involved in politics on an institutional or party level were aware of the connection between national issues and international problems and the importance of the upcoming changes and actively participated in the discussion by writing in party publications and other important magazines and print media of the time. ${ }^{32}$

Another important theme that comes to the fore in this collection of essays is the primary importance that ideology comes to have in the intellectual debate of the first years of the post-war period. Beginning with the end of the eighteenth century, the moment when the first reflections on the term ideology appeared, and up until very recently, multiple interpretations of the concept have been introduced, and the debate is far from being over. Without going into a detailed discussion of this key concept of the history of political thought, we would like to point out that the interpretation provided by Karl Mannheim, the founder of the sociology of knowledge, is particularly relevant for our studies. In 1929, Mannheim defined ideology as a system of visions, values and ideas that is capable of guiding political action and at the same time of expressing a conception of the world. ${ }^{33}$ In accordance with the tradition of marxist thought that he came from, the sociologist believed that an ideology expressed a vision of reality typical of a certain social group. However, unlike the marxists, Karl Mannheim emphasized the cognitive aspects of cultures and as a result considered the various points of view expressed within political ideologies as true, even when biased and contradictory. In fact, according to him, those points of view gained their truth precisely because they were expressions of a particular aspect of society and of the history of 
their time. Based on Mannheim's conception, in ideologies we are able to define a way of being of the dominant classes, rather than an instrument for domination or a form justifying one's power, and reflect on the social determinants that affect the visions of the world of each group. Indeed, Mannheim was also one of the first to highlight "a particular conception of the relations between theory and practice". 34

Ideologies, as we can see, are not false or true; they are not political doctrines or prescriptive philosophies. An ideology is a set of values, ideals and visions that expresses and affects a political action, a phenomenon that no doubt took place in Italy in 1945. As such, talking about the primacy of ideology does not represent a normative judgment of any sort. Such a reflection is not aimed at distinguishing between ideological and pragmatic intellectuals. Furthermore, reading politics through the lens of ideology in no way implicates a lack of awareness of the most important dynamics that define international politics during the decades that are being analyzed in this volume. For example, in their chapter, Ciglionil and Araminil analyze how the collaborators of Il Mulino-descendants of enlightenment culture, believers in the power of the social sciences to bring about social transformation - imagined themselves as having a collective role and committed themselves to progress and the improvement of the world; likewise, the liberal socialists, studied by Marco Bresciani in his chapter, emphasized the strong moral and ethical issue of their battle; and the catholic philosopher Augusto Del Noce considered the East-West détente to be part of a more general reflection on the process of secularization and impoverishment of Christian values in Europe. The protagonists of Italian culture that we examine here read international politics through the lens of certain values and ideas. From that point of view, even those more moderate and attentive to the needs of realism, even the ones who were least of all inclined to create alternative scenarios to the market economy and liberal democracy, expressed a vision of the world that was well defined and presented a system of ideals that could not be negotiated, a system we could define as ideological. ${ }^{35}$ Besides, it would be hard to make a clear distinction between the concrete needs of politics and the ideas of the intellectuals. An important Italian historian, Federico Chabod, made this observation many years ago in the Introduction to his Storia della politica estera italiana dal 1870 al 1896 (Italian Foreign Policy: The Statecraft of the Founders, 1870-1896). In this work from 1951, Chabod questioned the existence of so-called "permanent interests" in politics, that "sort of hidden divinity floating high above everything that constitutes the actual life of a people (political struggle, ideals and ideologies, passions in conflict) and forming both the precondition and the goal of foreign policy: a polar star on which to fix one's gaze in the course of a perilous voyage, disregarding everything else". ${ }^{36}$ He was convinced that the entire history of a nation - at least since the times of the French Revolution - with its aspirations and political ideologies, with its economic and social conditions, with its material possibilities and internal contrasts of affections and tendencies, impacted its decisions of an international nature. This is why he claimed that he does not recognize the abstract schemes of international or national politics or the primacy of one over the other, since both of them are closely interconnected.

Finally, a third theme that connects all of the chapters in this volume is related to historical periodization. Considering the breakdown of the agreements of Bretton Woods as a fundamental turning point in international relations, the chapters observe how Italian intellectuals developed a new, more informed approach to interpreting the bipolarity of international politics beginning from the second half of the 1960s. This approach saw a downplaying of the importance of the Cold War on the part of liberal socialists and many Catholics, whose reflections on the role of the United States were decidedly ambiguous. Without questioning Cold War affiliations and positions, these intellectuals, who openly belonged to the larger families of political Catholicism and liberal democracy, proposed Europe as an alternative model and experience to capitalism and the 
American society in general. Its capacity to guarantee Welfare State policies; its attention toward forms of income redistribution, its traditional commitment to economic policies; its identity as a culture that is vigilant in regard to the rights of the weak - all of these characteristics led many intellectuals to see Europe as the symbol of a supranational conception of politics, an identity and a means of differentiating oneself from American imperialism, from the nationalism of an ally that is imposing its role on the world. With the end of the 1960s and the Breton Woods system, many intellectuals grew more aware of Europe's divergent path, of its move toward a political and social model that was antithetical to that of the United States. During the Nixon and Reagan eras (even though there were some significant differences in their approaches), the United States tended to promote the primacy of the American interests, equating it, as usual, to the protection of Western values within the context of international bipolarity.

The reaction of an increasingly influential group of intellectual elites to this new project of American hegemony emphasized the idea of developing a supranational and multilateral European social system based on fairness and mutual support, which, however, would also simultaneously take advantage of the opportunities offered by a dynamic context of globalized economy and by the politics of monetarist nature introduced by the United States and the United Kingdom at the end of the 1960s. As some of the chapters in this volume demonstrate, it is in this precise context that the deep transformation of the "social function" of intellighentsja came about, from the progressive decline of the philosophical-enlightenment savant to the emergence of a new figure: the Intellectual-Mandarin. ${ }^{37}$ This figure was no longer meant to protect great ideals or create a general vision of the world. Instead, his new function was to successfully apply the "technique of governance", aimed at depoliticizing the public space and overcoming national interests in favor of a planned set of common goals.

This dynamic has a clearly paradoxical nature though. The technocratic culture of intellectualsmandarins, unwilling to adopt a pragmatic approach to the ongoing changes in political and social spheres, ended up supporting the faith in ideology as a collective force of the transformation of the reality. The myth of Europe as a "civil power" and a "third path" between American capitalism and socialism posited a vision of international relations based on the primacy of the economy and the law. This vision was not less utopian and definitive than the opposite hyper-political and globalist positions of American and Soviet origins. ${ }^{39}$ The idea, developed by Andreatta and Carli, the Secretaries of the Treasury, of using Europe as an instrument to compel political class to make institutional reforms at the end was supposed to reveal the intellectualistic and Jacobean attitude of the technicians. That idea was a clear expression of the open and radical intolerance toward the "actual" political reality as well as of a physiological resistance toward the idea of change on behalf of its main protagonists, political parties.

The 1970s would become an important turning point for socialists and communists as well: the rise of new issues, in Asia, in Africa and in Latin America, changed their relationship with the USSR, a relationship that had already been questioned by the socialists in the late 1950 s and opposed by the communists at the end of the 1960s. Although the socialists and communists were no longer stalinist and, as a result, were no longer bound by a logic of affiliation, even during the 1970s, they persisted in their severe criticism of liberal democracy, which they considered a sort of a transition toward a middle way between communism and Americanism. This is when the traditional and severe anti-Europeanism of PCI and PSI lost its radical nature and their position in the decades to follow started to move toward that of the catholics and liberal democrats. Even for the left, the idea of Europe became a possibility, an alternative to the American model, a space that was autonomous from both the United States and the USSR and equidistant from both blocs, a place where it would be possible to create a new world, an alternative to what already existed in 
the West. In the 1970s, when the myth of the USSR and of the inspirational force of the October Revolution started to fade, socialists and communists were trying to gain political weight on an international level by positing Europe in an anti-American stance. As Sorgonà observes, antiAmericanism has forever remained the North Star of the communists: however, Europe has assumed an auroral and palingenetic meaning, representing an alternative to the decaying reality of socialism.

Italian intellectuals end up taking their distance from the Western model, by criticizing the ideas of Occidentalism stands on, as well as the politics of traditional power, in this case with an accentuated attitude of pacifism, anti-Americanism ${ }^{41}$ and solidarity toward the Third World. From that point of view, it would not be unfounded to conclude that Italian intellectuals have maintained a sort of ambiguity: they contributed to the construction of a country and its approach to international politics, they held important roles, they served the interests of politics, they used their energy to produce a vision of the world following the path begun in 1861 which saw their names inscribed into the history of the nation. At the same time, the intellectuals were the main critics of liberal and Western democracy, even though they were part of it, and by doing this they contributed to an increasing withdrawal of the educated classes from the politics of Western governments, the consequences of which we are still feeling today.

\section{Bibliography}

Acanfora, Paolo. Miti e ideologia nella politica estera della DC. Nazione, Europa e Comunità atlantica (1943-1954). Bologna: Il Mulino, 2013.

Aga Rossi, Elena, Victor Zaslavski. Togliatti e Stalin. Il Pci e la politica estera negli archivi di Mosca. Bologna: Il Mulino, 1997.

Ardia, Danilo. Il partito socialista e il patto atlantico. FrancoAngeli: Milano, 1976.

Attal, Frédéric. Histoire des intellectuels italiens au 20eme siecle: prophètes, philosophes et experts. Paris: Les Belles Lettres, 2013.

Bailey, Leon. Critical Theory and the Sociology of Knowledge. A comparative study in the Theory of Ideology. New York: Peter Lang, 1994.

Balkin, Jack M. Cultural software. A theory of Ideology. New Haven - London: Yale University Press, 1998.

Bell, Daniel. The end of Ideology. On the Exhaustion of Political Ideas in the Fifties. New York: Harvard University Press, 2000.

Benzoni, A. I socialisti e la politica estera, in La politica estera della repubblica italiana, vol. III. Milano: Edizioni di Comunità, 1967.

Bodei, Remo. L'ethos dell'Italia repubblicana, in Storia dell'Italia repubblicana, Francesco Barbagallo, ed., volume 3, tomo II, L'Italia nella crisi mondiale. L'ultimo ventennio. Turin: Einaudi, 1997.

Bonanni, Massimo, eds. La politica estera della Repubblica italiana. Milano: Edizioni di 
Comunità, 1967, 3 voll.

Bonfreschi, Lucia. Raymond Aron e il gollismo (1940-1969). Soveria Mannelli: Rubbettino, 2014.

Bonfreschi Lucia, Maccaferri, Marzia., eds. Intellettuali europei e politica estera nella seconda metà del Novecento, in "Memoria e ricerca", 1/2016.

Brighi, Elisabetta, Rosenboim, Or. "Realismo e geopolitica in Italia durante la guerra fredda: tramonto o rinascita?," Memoria e ricerca, 24, n. 1, April 2016.

Bruno Bongiovanni. "Gli intellettuali e i miti del dopoguerra", in Storia d'Italia, vol. 5, La

Repubblica, Giovanni Sabbatucci, Vittorio Vidotto, ed., Bari-Rome: Laterza, 1997.

Calì, V., Corni, Gustavo, Ferrandi, G., eds. Gli intellettuali e la Grande Guerra. Bologna: Il Mulino, 2000.

Campi Alessandro, De Luca Stefano, eds. Il realismo politico. Figure, concetti, prospettive di ricerca. Soveria Mannelli: Rubbettino, 2014.

Caute, David. The Dancer Defects. The struggle for cultural supremacy during the Cold War. Oxford: Oxford University Press, 2005.

Chabod, Federico. Storia della politica estera italiana dal 1870 al 1896, vol. 1. Bari: Laterza, 1971.

Charle, Christophe. Gli intellettuali nell'Ottocento. Saggio di storia comparata europea. Bologna: il Mulino, 2002.

Chianta, Carmelina C. Ricostruire la società. Teoria del mutamento sociale in Karl Mannheim. Milan: FrancoAngeli, 2006.

Craveri, Piero. De Gasperi. Bologna: Il Mulino, 2006.

Craveri, Piero, Quagliariello, Gaetano, eds. L'antiamericanismo in Italia e in Europa nel secondo dopoguerra. Soveria Mannelli: Rubbettino, 2004.

D’Orsi, Angelo. I chierici alla guerra. La seduzione bellica sugli intellettuali da Adua a Baghdad. Turin: Bollati Boringhieri, 2005.

Del Pero, Mario. L'alleato scomodo. Gli Usa e la DC negli anni del centrismo (1948-1955). Roma: Carocci, 2001.

Di Nolfo, Ennio. Il socialismo italiano tra i due blocchi, in Trent'anni di politica socialista, Atti del Convegno di Parma, gennaio 1977, Roma: Mondo Operaio, 1977.

Dyson, Kenneth, Ivo Maes, eds. Architects of the Euro, Intellectuals in the Making of European Monetary Union, Oxford: Oxford University Press, 2016.

Eagleton, T. Ideology. An introduction. London - New York: Verso, 2007. 
Formigoni, Guido. La Democrazia cristiana e l'alleanza occidentale: 1943-1953. Bologna: il Mulino, 1996.

Formigoni, Guido. L'Italia dei cattolici: fede e nazione dal Risorgimento a oggi. Bologna: il Mulino, 1998.

Formigoni, Guido. Storia d'Italia nella guerra fredda (1943-1978). Bologna: il Mulino, 2016.

Freeden, Michael. Ideologies and Political Theory: a conceptual approach. Oxford: Clarendon Press, 1996.

Gaeta Franco. Il nazionalismo italiano. Roma-Bari: Laterza, 1981.

Gentile Emilio. La Grande Italia. Ascesa e declino del mito della nazione nel ventesimo secolo. Milano: Mondadori, 1997.

Gienow-Hetch, C.E.J. Culture and the Cold War in Europe, in The Cambridge History of the Cold War, vol. I, Origins, Leffler Melvyn P., Westad Odd Arne. Cambridge: Cambridge University Press, 2010.

Gilman Nils. Mandarins of the Future. Modernization Theory in Cold War America. Baltimore: The John Hopkins University Press, 2003.

Giovagnoli, Agostino. La cultura democristiana. Tra chiesa cattolica e identità italiana 1918-1948. Bari-Rome: Laterza, 1991.

Giovagnoli, Agostino. La Repubblica degli italiani (1946-2006). Bari-Roma: Laterza, 2017.

Graglia, Piero S. "Altiero Spinelli e la genesi dello IAI: il federalismo, il gruppo de "Il Mulino" e la dimensione internazionale del lavoro culturale." In Altiero Spinelli e i movimenti per l'unità europea, ed., Daniela Preda. Padova: CEDAM, 2010.

Guiso, Andrea. “Il PCI e la sua storia: come cambiano i paradigmi”, in I partiti politici nell'Italia repubblicana, Gerardo Nicolosi, ed., Soveria Mannelli: Rubbettino, 2006.

Guiso, Andrea. La colomba e la spada. "Lotta per la pace” e antiamericanismo nella politica del Partito Comunista Italiano (1949-1954). Soveria Mannelli: Rubbettino, 2007.

Hall, Ian. Dilemmas of Decline. British Intellectuals and World Politics, 1945-1975. University of California Press, 2012.

Heywood, A. Political ideologies. An introduction. London: Basingstoke, 1992.

Hixson, Walter L. Parting the Curtain. Propaganda, Culture, and the Cold War. 1941-1965. Basingstoke: Macmillan, 1997.

Isnenghi, Mario. Il mito della Grande Guerra. Bologna: il Mulino, 1997 (first edition Bari: Laterza, 1969).

Jennings Jeremy, ed. Intellectuals in Twentieth-Century France. Mandarins and Samurais, New 
York: Palgrave Macmillan 1993.

Judt, Tony. Past Imperfect. French Intellectuals: 1944-1956. Berkeley: University of California Press, 1992.

Judt, Tony, Denis Lacorne, eds. With Us or Against Us. Studies in Global Anti-Americanism, New York: Palgrave Macmillan, 2005.

Knight, K. Transformations of the Concept of Ideology in the Twentieth Century, in "American Political Science Review”, 2006, 100, 4.

Latham, Michael E. Modernization as Ideology. American Social Science and Nation Building in the Kennedy Era. Chapel Hill and London: University of North Caroline Press, 2000.

Leonardi, Silvio. L'Europa e il movimento socialista. Considerazioni sui processi comunitari Cee e Comecon, Milano: Adelphi, 1977.

Lill Rudolf, and Valsecchi, Franco, eds. Il nazionalismo italiano in Italia e in Germania, fino alla prima guerra mondiale. Bologna: Il Mulino, 1983.

Lomellini, Valentine, Varsori, Antonio, eds. Dal Sessantotto al crollo del Muro: i movimenti di protesta in Europa a cavallo tra i due blocchi. Milano: Franco Angeli, 2013.

Mangoni Luisa. Lo Stato unitario liberale, in Letteratura italiana, I, Il letterato e le istituzioni. Turin: Einaudi, 1982.

Mangoni, Luisa. "Civiltà della crisi”, in Storia dell'Italia repubblicana, vol. 1, La costruzione della democrazia, Francesco Barbagallo, ed., Turin: Einaudi, 1994.

Mannheim, Karl. Ideologia e Utopia. Bologna: Il Mulino, 1957.

Mitter, Rana, and Patrick Major, eds. Across the Blocs. Cold War Cultural and Social History. London, Portland, OR: Frank Cass 2004.

Moro, Renato. La formazione della classe dirigente cattolica (1929-1937). Bologna: Il Mulino, 1979.

Mosse, George. La nazionalizzazione delle masse. Simbolismo politico e movimenti di massa in Germania (1813-1933). Bologna: Il Mulino, 1975.

Nardi I., and S. Gentili, eds. La grande illusione. Opinione pubblica e mass media al tempo della guerra di Libia. Perugia: Morlacchi, 2009.

Nenni, Pietro. I nodi della politica estera italiana, Domenico Zucaro, ed., Milano: Sugarco, 1974.

Nuti, Leopoldo. Gli Stati Uniti e l'apertura a sinistra. Importanza e limiti della presenza americana in Italia. Bari-Rome: Editori Laterza,1999.

Osgood, Kenneth. The Total Cold War. Eisenhower Secret Propaganda Battle at Home and Abroad. Lawrence: University Press of Kansas, 2006. 
Parlato, Giuseppe. Fascisti senza Mussolini: le origini del neofascismo in Italia, 1943-1948. Bologna: Il Mulino, 2006.

Parlato, Giuseppe. La sinistra fascista: storia di un progetto mancato. Bologna: il Mulino, 2000.

Perfetti Francesco. Studi sul nazionalismo italiano. Genova: Ecig, 1984.

Pesetti, Lucio. L’internazionale socialista dal 1951 al 1983. Venezia: Marsilio, 1989.

Pinto, Carmine. Il riformismo possibile. La grande stagione delle riforme: utopie, speranze, realtà (1945-1964). Soveria Mannelli: Rubbettino, 2008.

Pnf. La cultura fascista. Roma: Istituto poligrafico dello Stato, 1936.

Pombeni, Paolo. La costituente. Un problema storico-politico. Bologna: il Mulino, 1995.

Pombeni, Paolo. Il gruppo dossettiano e la fondazione della democrazia italiana (1938-1949). Bologna: Il Mulino, 1979.

Pons, Silvio. L'Unione Sovietica nella politica estera di Togliatti (1944-1949), in "Studi Storici”, 33, 2, 1992.

Pons, Silvio. La politica estera dell'Urss. Il Cominform e il Pci, (1947-1948), in "Studi Storici”, $35,4,1994$.

Pons, Silvio. L'impossibile egemonia. L'Unione Sovietica, il Partito Comunista Italiano e le origini della guerra fredda (1943-1948). Roma: Carocci, 1999.

Pons, Silvio. La rivoluzione globale. Storia del comunismo internazionale, 1917-1991, Turin: Einaudi, 2012.

Posner, Richard A. Public Intellectuals. A Study of Decline. Cambridge Massachusetts-London: Harvard University Press, 2001.

Sabbatucci, Giovanni, and Vittorio Vidotto, eds. Storia d'Italia, vol. 6, L'Italia contemporanea. Bari-Rome: Laterza, 1999.

Schiavulli, Antonio, ed. La guerra lirica. Il dibattito dei letterati italiani sull'impresa di Libia (1911-1912), Ravenna 2009. Ferrandi, ed., Gli intellettuali e la Grande guerra, il Mulino.

Schulz-Forberg, and Hagen, Bo Stråth. The Political History of European Integration. The Hypocrisy of Democracy-Through-Market. New York - Abingdon: Routledge, 2010.

Scirocco, Giovanni. "Politique d'abord”. Il Psi, la guerra fredda e la politica internazionale (1948-1957). Milano: Unicopli, 2010.

Sorgonà, Gregorio. La scoperta della destra. Il Movimento Sociale Italiano e gli Stati Uniti. Roma: Viella, 2019. 
Sounders, Frances Stonor. Who Paid the Piper? The Cia and the Cultural Cold War. London: Granta Books, 1999.

Sowell, Thomas. Intellectuals and society. New York: Basic Books, 2012.

Tarquini, Alessandra. Storia della cultura fascista. Bologna: Il Mulino, 2011.

Tarquini, Alessandra, ed. Il primato della politica nell'Italia del Novecento. Studi in onore di Emilio Gentile. Bari-Rome: Laterza, 2016.

Telò, Mario. L'Europa potenza civile. Bari-Roma: Laterza, 2004.

Thompson, John B. Ideology and Modern Culture. Critical Social Theory in the Era of Mass Communication. Cambridge: Polity Press, 1990.

Tobia, Bruno. Una patria per gli italiani. Spazi, itinerari, monumenti nell'Italia unita (1870-1900). Roma-Bari: Laterza, 1991.

Traniello, Francesco. Città dell'uomo. Cattolici, partito e Stato nella storia d'Italia. Bologna: Il Mulino, 1998.

Ungari, Andrea, and Monzali, Luciano. I monarchici e la politica estera italiana nel secondo dopoguerra. Soveria Mannelli: Rubbettino, 2013.

Vittoria, Albertina. Togliatti e gli intellettuali. La politica culturale dei comunisti italiani (1944-1964). Roma: Carocci, 2014.

Zaslavsky, Victor. Lo stalinismo e la Sinistra Italiana. Dal mito dell'URSS alla fine del comunismo 1945-1991. Milano: Mondadori, 2004.

G. Formigoni, Storia d'Italia nella guerra fredda.

R. Bodei, L'ethos dell'Italia repubblicana.

The theme of international politics is not considered in any way in the nevertheless brilliant essay on the intellectuals in republican Italy written by Pierluigi Battista, in Giovanni Sabbatucci, Vittorio Vidotto, ed., Storia d'Italia, vol. 6, L'Italia contemporanea, 439-539. This consideration also regards the dense essay by Luisa Mangoni, "Civiltà della crisi". We can find several short and abrupt mentions of the relationship between the culture and international context in Bruno Bongiovanni: "Gli intellettuali e i miti del dopoguerra".

Hixson, Parting the Curtain. Mitter and Majon, ed., Across the Blocs. Sounders, Who Paid the Piper? Caute, The Dancer Defects. Gienow-Hetch, Culture and the Cold War in Europe.

Osgood, The Total Cold War. Reports among the first attempts to reconstruct the role of intellectuals in relation to international politics in Italy and Europe cf. Bonanni, ed., La politica estera della Repubblica italiana, vol. 1; Bonfreschí and Maccaferri, Intellettuali europei e politica estera.

6 See Judt, Past Imperfect. See also Bonfreschi, Raymond Aron $e$ il gollismo.

For a clearer idea of these problems, see Charle, Gli intellettuali nell'Ottocento. On Italian case see Attaire des intellectuels italiens au 20eme siecle.

Mosse: La nazionalizzazione delle masse. On Italian nationalism for that concerned here cf. some very different interpretations: Gaeta, Il nazionalismo italiano. Lill, Valsecchi, ed., Il nazionalismo italiano in Italia e in Germania. Perfetti, Studi sul nazionalismo italiano. Tobia, Una patria per gli italiani. Gentile, La Grande Italia, 24.

Gentile, La Grande Italia, 64-70.

10 Ivi, 73

11 Mangoni, Lo Stato unitario liberale, 511. D’Orsi, I chierici alla guerra. Nardi, Gentili, La grande illusione. Schiavulli La guerra lirica. Calì, Corni, ,Ferrandi, eds., Gli intellettuali e la Grande guerra. Isnenghi, Il mito della Grande Guerra. 


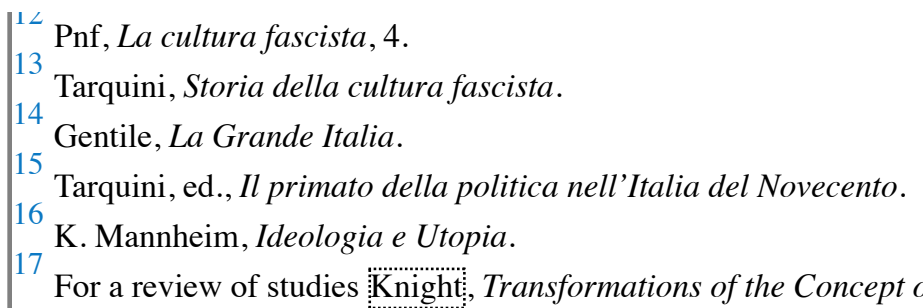
classic Bell, The end of Ideology. 395. Thompson, Ideology and Modern Culture. Freeden, Ideologies and Political Theory. Balkin, Cultural software. Heywood, Political ideologies. Eagleton, Ideology. An introduction.

18 Giovagnoli, La cultura democristiana. Traniello, Città dell'uomo. Moro, La formazione della classe politica cattolica . Formigon, L'Italia dei cattolici.

Pombeni|, La costituente. Id., La nascita del gruppo dirigente dossettiano.

${ }^{20}$ Craveri, De Gasperi. Formigoni, Dc e alleanza atlantica. Del Pero, L'alleato scomodo. Acanfora, Miti e ideologia nella politica estera della DC.

21 Giovagnoli, La repubblica degli italiani.

22 Pintol, Il riformismo possibile, 62.

23 On the foreign policy of the PSI: Nuti, Gli Stati Uniti e l'apertura a sinistra; Benzoni, I socialisti e la politica estera, 927-949. Nenni, I nodi della politica estera italiana. Ardia, Il partito socialista e il patto atlantico. Di Nolfo, Il socialismo italiano tra i due blocchi, 47-66; Scirocco"' "Politique d'abord". For the clash between PSI and the International Socialist between 1948 and 1949, cf. Pesetti, L'internazionale socialista dal 1951 al 1983, 14-20.

${ }^{24}$ Di Nolfo, Il socialismo italiano tra i due blocchi, 56.

25 Scirocco, "Politique d'abord", 21.

${ }^{26}$ Cf. Vittoria, Togliatti e gli intellettuali, 24-66.

27 Pons: L'Unione Sovietica nella politica estera di Togliatti, 435-456. Pons: La politica estera dell'Urss, 1123-1147; Pons, L'impossibile egemonia. Zaslavsky, Lo stalinismo e la Sinistra Italiana. Aga Rossi, Zaslavski, Togliatti e Stalin. Guiso, La colomba e la spada.. In our opinion, it is hard to agree with the approach of Bruno Bongiovanni, who defines the PCI as "a social democracy dedicated to forming a republic and not a revolution", pro-Soviet and "Stalinist enough to "maintain the assets that have been built up thanks to the rescue of Stalingrad". This approach downsizes significantly the importance of the political ideological factor as well as the primacy of international politics in the culture of international and Italian communism. Cf. Bruno Bongiovanni, "Gli intellettuali e i miti del dopoguerra". For the critique of the analogy between communist and social-democratic cultures cf. Guiso, "Il PCI e la sua storia: come cambiano i paradigmi”. On the culture of international communism during the years of the Cold War, see Silvio Pons, La rivoluzione globale.

${ }^{28}$ See Latham, Modernization as Ideology. Gilman, Mandarins of the Future.

29

Del Pero, L'alleato scomodo.

Which does not mean not recognizing, even to these forces, having contributed to promoting orientations and visions of international politics. Cf. Sorgonà, La scoperta della destra; Ungari, Monzali, I monarchici e la politica estera italiana nel secondo dopoguerra.

31 Parlato, Fascisti senza Mussolini. Id., Il fascismo di sinistra.

${ }^{32}$ For a similar approach to the topic of relations between intellectuals and international politics, see Hallemmas of Decline.

33 Mannheim, Ideologia e Utopia.

Ivi, 131. Among other bibliography cfr. Bailey, Critical Theory and the Sociology of Knowledge. Chiantal, Ricostruire la società.

35 Another topic that we cannot address here is the impact of intellectuals and philosophers, such as Morgenthau, Niebuhr, Aron, De Jouvenel, Freund, Carr, representing in several different forms realism in politics. Their works were not taken into consideration in the public debate until the 1980s and later. On this topic, see Campi, De Luca, eds., Il realismo politico. See also Brighi and Rosenboim, "Realismo e geopolitica in Italia durante la guerra fredda: tramonto o rinascita?". 36 Chabod, Storia della politica estera italiana, 11.

${ }^{37}$ See Jennings: ed., Intellectuals in Twentieth-Century France. Posner, Public Intellectuals. Sowell: Intellectuals and society.

38 The connection between Europeanism and the development of technical competencies regarding the international politics in the context of political parties can be proved by the emergence of some important think tanks, such as Istituto Affari Internazionali (IAI), connected to the figure of Altiero Spinelli and Cespe, initiated by Enrico Berlinguer, in the 1960s and 1970s. On the foundation of the IAI, see Graglia, 'Altiero Spinelli e la genesi dello IAI'”,'245-77."

On the opposite rhetorics of the American dream and Soviet myth in post-war Italy, see D'Attorre, ed., Nemici per la pelle.

${ }^{40}$ On Europe as a civil power, see Telö, L'Europa potenza civile. For a reflection from the inside of the PCI on Europe as a middle way between the two opposed powers of the Cold War, see Leonardi, L'Europa e il movimento socialista... On the intellectual conditions of the Common Currency, see Dyson, Maes, ed., Architects of the Euro. See also Schulz-Forberg, 
Strâth, The Political History of European Integration.

See Judt and Lacorne, ed., With Us or Against Us. For a historical perspective, see also Lomellini, Varsori, eds., Dal Sessantotto al crollo del Muro; Craveri, Quagliariello, ed., L'antiamericanismo in Italia e in Europa. 